\title{
Palatal Rugae: Systematic Analysis of its Shape and Dimensions for Use in Human Identification
}

\author{
Rugas Palatinas: Sistematización del Análisis de su Forma \\ y Dimensiones para su Uso en Identificación Humana
}

"Valeria Hermosilla Venegas; ${ }^{* *}$ Jaime San Pedro Valenzuela; ${ }^{* * * *}$ Mario Cantín López \& ${ }^{* * *}$ Iván Claudio Suazo Galdames

HERMOSIlla, V. V.; SAN PEDRO, V. J.; CANTÍN, L. M. \& SUAZO, G. I. C. Palatal rugae: systematic analysis of its shape and dimensions for use in human identification. Int. J. Morphol., 27(3):819-825, 2009.

SUMMARY: Establish a person's identity can be a very complex process, one of the main objectives of the forensic sciences. The analysis of the teeth, fingerprints and DNA comparison, are probably the most used technics, allowing fast and secure identification processes. However, these techniques can not always be applied, in some cases, it is necessary to apply different and less known techniques. In this work, a systematic analysis of the shape and dimensions of the palatal rugae was performed. We analyzed 120 subjects of both sexes, between 15 to 20 years olds, fully dentated, and by calcorrugoscopy were determined the shape, size, number and position of the palatal rugae. The most prevalent palatal rugae shape was sinuous ( $43 \%)$ followed by curve $(27 \%)$, line $(15 \%)$, point $(11 \%)$, and polymorphic varieties (4\%). The average number was 12.27, being higher in male than female. The palatal rugae that were larger were the sinuous (mean $9.58 \mathrm{~mm}$ ). $40 \%$ of the rugae were found in the E quadrant, followed by D (30\%), the rest was distributed among the other regions. The analysis of the palatal rugae and their features can be used as a reliable guide to the forensic identification.

KEY WORDS: Palatal rugae; Palate; Rugoscopy; Forensic; Human identification.

\section{INTRODUCTION}

Transverse palatine folds or palatal rugae (PR), are asymmetrical and irregular elevations of the mucosa located in the anterior third of the palate, made from the lateral membrane of the incisive papilla, arranged in transverse direction from palatine raphe located in the midsagittal plane. These formations have been used in medicolegal identification processes because their individual morphological characteristics and stable over time (Thomas \& van Wyk, 1988; English et al., 1988; Caldas et al., 2007; Patil et al., 2008).

The palatal rugae appear towards the third month of intrauterine life, from the covering connective tissue in the palatine process of maxillary bone, and its development and growth is mutually controlled by epithelial-mesenchymal interactions, where specific extracellular matrix molecules are spatiotemporally expressed during development (Amasaki et al., 2003). The first rugae is distinguished in human embryos of $32 \mathrm{~mm}$ CRL (Butchtová et al., 2003) next to the incisive papilla. Then, in the prenatal stage are relatively prominent (Gegenbaur, 1878, Waterman \& Meller, 1974), the PR at birth are well trained with a typical orientation pattern (Gegenbauer) and adolescence acquire the final feature shape of each individual ( Yamazaki, 1962). Once they are formed may experience changes in their size due to growth of the palate, but its shape is maintained (Jordanov, 1971, Lang \& Baumeister, 1984).

Physiologically the palatal rugae are involved in the oral swallowing and help to improve the relationship between food and the taste receptors in the dorsal surface of the tongue (Buchtová et al.), also participated in speech and in the suction in children (Thomas et al., 1987).

The PR form elevations more or less prominent and take various configurations. Its design and structure are

\footnotetext{
* Cirujano Dentista, práctica privada.

** Departamento de Estomatología. Facultad de Ciencias de la Salud, Universidad de Talca, Chile.

**** Morfología, Facultad de Ciencias de la Salud, Universidad de Talca, Chile.
} 
unchanged and are not altered by chemicals, heat, disease or trauma, or, if palatal rugae are destroyed, are reproduced exactly on the same site that had (Almeida et al., 1995). Form, layout and characteristics are not affected by the eruption of the teeth or their loss, but sometimes palatal rugae adjacent to the alveolar arch slightly change their position after tooth extraction (Peavy \& Kendrick, 1967). However, some events may contribute to changes in the pattern of PR, such as finger sucking in childhood and persistent pressure due to orthodontic treatment. Furthermore, it has been reported that extractions can produce a local effect on the direction of the PR (Limson \& Julian, 2004).

The PR has been considered relevant for human identification due to its stable (Muthusubramanian et al., 2005), being equivalent to the fingerprint, unique for each individual (Limson \& Julian), his study on the identification of persons is called palatoscopy or palate rugoscopy (Caldas et al.). However, analysis of their shapes and dimensions are poorly described. Therefore, the purpose of this study is to describe the shape and biometric characteristics of the palatal rugae, analyzing their prevalence in a sample of 120 adult subjects.

\section{MATERIAL AND METHOD}

By non-probability convenience sampling were selected 120 students and patients of the Center for Clinical Dentistry, Universidad de Talca, 60 male and 60 female between 15 and 50 years olds, fully maxillary toothed, without considering the third molar. The subjects were informed of the nature of this study and agreed to participate, leaving a written record of its acceptance. Were excluded from this study patients with severe maloclussions, with palatal asymmetries and palate with a history of surgery or giving it.

Maxillary plaster models were obtained, on which to place the calcorrugoscopy (Fig.1). Subsequently, the information obtained was recorded in a rugoscopy record or rugograma, including: shape, number, size and position of the palatal rugae and using the SPSS 15.0 statistical descriptors were identified for each of these parameters.

Shape analysis. The shape of the palatine rugae was registered according to the classification of Trobo (Pueyo et al., 1994). This classification also divides rugae into two groups: Simple rugae, classified as ABCDEF, where rugaes shapes are well defined, and Composed rugae, classified as type $\mathrm{X}$, with a polymorphisms variety (these rugaes composed result of the union of two or more simple rugaes). This classification is in Table I. Then he made a rugograma, from the right side and then the left side, starting with the main ruga (closest to the palatal raphe), which was classified with a capital letter, and then rugae were classified with lower case letters $(\mathrm{Cal}-$ das et al.).

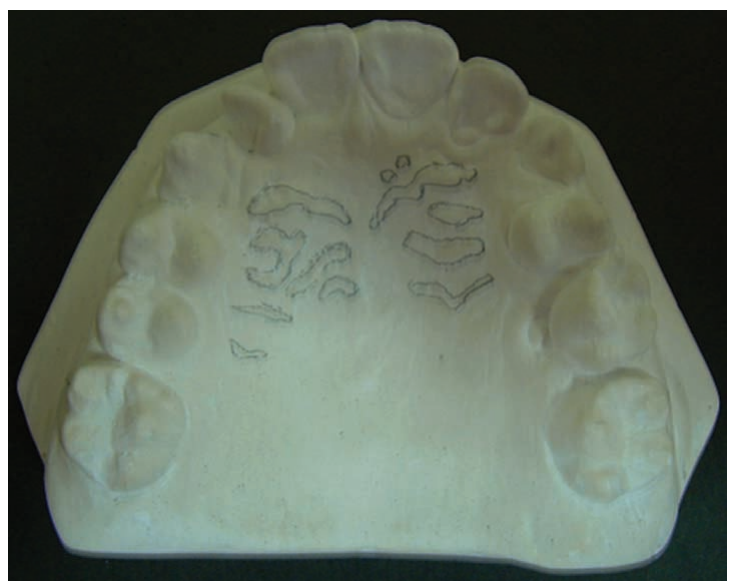

Fig. 1. Calcorrugoscopy in plaster model.

Table I. Palatal rugae classification by Trobo.

\begin{tabular}{ccc}
\hline Clasification & Rugae type & Shape \\
\hline Type A & Point & \\
& &
\end{tabular}

Type B

Line

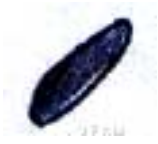

Type C Curve

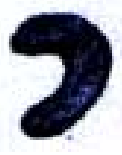

Type D

Angle

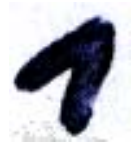

Type E Sinuous

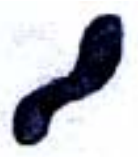

Type F Circle

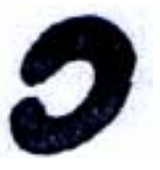


Number analysis. There were all palatal rugae that were totally bounded in calcorrugoscopy.

Size analysis. Using a digital caliper $(0.01 \mathrm{~mm})$ found the maximum longitudinal diameter of all palatal rugae accounted, according to the corresponding type under the classification of shape.

Position analysis. To analyze the position of the palatal rugae were standardized photographs of models obtained and using Photoshop software (Adobe ${ }^{\circledR}$ Photoshop ${ }^{\circledR}$ CS4) palate was divided into quadrants, with the aim of obtaining the coordinates position of palatal rugae; for this, six horizontal lines:

I. Transverse line passing through the palatal cervical third of the central incisors.

II. Transversal line that goes from the mesial side of the right lateral incisor to the mesial side of the left lateral incisor.

III. Transverse line through the mesial side of the right canine and reaches to the mesial side of the left canine.

IV. Transverse line through the mesial side of the right first premolar and reaching to the mesial side of the left first premolar.

V. Transverse line through the mesial side of the right second premolar and reaching to the mesial side of the left second premolar.

VI. Transverse line through the distal side of the second premolar and reaching to the right side of the distal left second premolar.

Based on these lines between the areas they were named as follows:
A. Between lines I and II.
B. Between lines II and III.
C. Between lines III and IV.
D. Between lines IV and V.
E. Between lines V and VI.

\section{RESULTS}

Shape. The most prevalent shape of palatal rugae was the sinouos (43\%), followed by the curve (27\%), line (15\%), point $(11 \%)$ and polymorphic varieties $(4 \%)$. There were no angled rugae or circle on the sample type analyzed. The details of the distribution of the rugae shape by sex is in Table II.

Number. The average of palatal rugae account in the total sample was 12.27 (SD 1.98), this value being slightly higher in the palates of men than women, although without significant differences. The details of these values is in Table III.

Size. The resulting larger palatal rugae were sinuous, with a mean of $9.58 \mathrm{~mm}$ (SD 3.05), details of the dimensions in the different types of palatal rugae is found in Table IV.

Position. Forty percent of the rugae were found in the E quadrant, followed by the D quadrant in which we found $30 \%$ of rugae. The remaining percentage was distributed in the other regions where the palate was divided. The detail of the position of the palatal rugae analyzed by standardized photographs analysis are in Table V.

\section{DISCUSSION}

The palatal rugae like fingerprints do not change during the life of the individual, are protected from trauma and high temperatures for its internal position in the oral cavity, surrounded and protected by lips, cheeks, tongue, teeth and bone, also prosthetic devices are not affected. Once formed, only changed in its length, due to normal growth, staying in the same position throughout the life of a person. Even disease, trauma or chemical attack seem able to change the shape of the palatal rugae (Almeida et al.).

There are different ways to analyze the palatal rugae. Intraoral inspection is probably the most used and most easily and economically method. However, this can create difficulties if a future comparative review is required. A more detailed and accurate, and the need to preserve evidence may justify the use of photographs or impressions (Utsuno et al., 2005). While observing the shape of the rugae is a subjective process, it is relatively easy to record and does not require complex instrumentation.

In this study, the palatal rugae most commonly were the sinuous and curves, representing $72.5 \%$ of the total population, which coincides with that observed in Caucasian andAboriginal Australians (Kapali et al., 1997), and in two populations Indies (Preethi et al., 2007). These results suggest the utility and easy to compare the reproducibility of palatal rugae for human identification, in both edentulous and dentate individuals. It is important to make a proper selection of cases, taking into account the diversity of forms that may arise, knowing where their population-specific, can be an increase in the rate of accuracy of identification with this method, approach $100 \%$ of cases (Otahi et al., 2008).

For the other issues addressed, is complex to compa- 
HERMOSILLA, V. V.; SAN PEDRO, V. J.; CANTíN, L. M. \& SUAZO, G. I. C. Palatal rugae: systematic analysis of its shape and dimensions for use in human identification. Int. J. Morphol., 27(3):819-825, 2009.

Table II. Shape of the palatal rugae by Trobo classification, subdivided by sex.

\begin{tabular}{cccccc}
\hline Palatine rugae shape & n & Mean & SD & Maximum & Minimum \\
\hline Females & 60 & 1.51 & 1.42 & 5 & 0 \\
A & 60 & 0.93 & 1.56 & 6 & 0 \\
B & 60 & 3.63 & 1.96 & 8 & 0 \\
C & 60 & 0.016 & 0.12 & 1 & 0 \\
D & 60 & 5.15 & 1.56 & 9 & 2 \\
E & 60 & 0.008 & 0.091 & 1 & 0 \\
F & 60 & 0.41 & 0.71 & 3 & 0 \\
X & & & & & \\
Males & 60 & 0.016 & 1.57 & 6 & 0 \\
A & 60 & 1.78 & 1.3 & 5 & 0 \\
B & 60 & 3.08 & 1.8 & 7 & 0 \\
C & 60 & 0.016 & 0.12 & 1 & 0 \\
D & 60 & 5.51 & 2.02 & 11 & 1 \\
E & 60 & 0.016 & 0.12 & 1 & 0 \\
F & 60 & 0.48 & 0.65 & 2 & 0 \\
X & & & & & \\
Total & 120 & 1.4 & 1.49 & 6 & 0 \\
A & 120 & 1.85 & 1.43 & 6 & 0 \\
B & 120 & 3.35 & 1.9 & 8 & 0 \\
C & 120 & 0.016 & 0.12 & 1 & 0 \\
D & 120 & 5.33 & 1.81 & 11 & 1 \\
E & 120 & 0.008 & 0.091 & 1 & 0 \\
F & 120 & 0.45 & 0.68 & 3 & 0 \\
X & & & & &
\end{tabular}

Table III. Distribution of palatal rugae in a sample of 120 calcorrugoscopy analysis.

\begin{tabular}{cccccc}
\hline Palatine rugae & $\mathbf{n}$ & Mean & SD & Maximum & Minimum \\
\hline Females & 60 & 12.33 & 1.77 & 17 & 8 \\
Males & 60 & 12.21 & 2.19 & 18 & 8 \\
Total & 120 & 12.27 & 1.98 & 18 & 8 \\
\hline
\end{tabular}

re these results with the literature because the small number of similar reports. Some authors suggest the presence of sexual dimorphism in the biometric features of the palatal rugae, which we can not argue with our results (Yamazaki, Reuer, 1973). In the limited literature of the subject, is clear a lack of uniformity in nomenclature, making it more difficult to compare the results, it is the majority of methods developed individually, and not validity information reported, with low reproducibility, and due to the importance of describing the rugoscopy characteristics in dental-forensic expertise, we suggest developing a standard method for evaluation of palatal rugae, as described in this study.

The palatoscopy is a technique that can be of great interest in human identification. In fact, contrary to the lips that are printed, it is possible to obtain ante-mortem data stable over time, such records that are in dental practice in its various forms (dental casts, intraoral photographs and dental prostheses). However, palatoscopy might not be as useful in investigations of crime scenes and in linking 
HERMOSILLA, V. V.; SAN PEDRO, V. J.; CANTíN, L. M. \& SUAZO, G. I. C. Palatal rugae: systematic analysis of its shape and dimensions for use in human identification. Int. J. Morphol., 27(3):819-825, 2009.

Table IV. Size of palatal rugae in different types and sex.

\begin{tabular}{cccccc}
\hline $\begin{array}{c}\text { Palatine rugae size } \\
\text { (measured in mm) }\end{array}$ & $\mathbf{n}$ & Mean & SD & Maximum & Minimum \\
Total & & & & & \\
A & 120 & 1.64 & 0.71 & 6.99 & 0.56 \\
B & 120 & 5.21 & 2.18 & 12.95 & 1.26 \\
C & 120 & 6.54 & 2.69 & 14.97 & 2.1 \\
D & 120 & 8.59 & 2.2 & 13.3 & 6.51 \\
E & 120 & $9.58^{*}$ & 3.05 & 20.04 & 0.75 \\
F & 120 & 7.56 & 0.99 & 8.27 & 6.86 \\
X & 120 & 9.09 & 2.09 & 13.11 & 2.31 \\
Females & & & & & \\
A & 60 & 1.62 & 0.76 & 6.99 & 0.57 \\
B & 60 & 5.22 & 1.99 & 12.82 & 1.38 \\
C & 60 & 6.48 & 2.71 & 14.97 & 1.5 \\
D & 60 & 8.41 & 1.19 & 9.64 & 6.78 \\
E & 60 & $9.58^{*}$ & 2.92 & 16.47 & 0.75 \\
F & 60 & 8.27 & - & 8.27 & 8.27 \\
X & 60 & 8.67 & 2.46 & 13.11 & 2.31 \\
Males & & & & & \\
A & 60 & 1.66 & 0.71 & 3.79 & 0.56 \\
B & 60 & 5.2 & 2.38 & 12.95 & 1.26 \\
C & 60 & 6.6 & 2.68 & 13.11 & 2.1 \\
D & 60 & 8.77 & 3.14 & 13.3 & 6.51 \\
E & 60 & $9.76^{*}$ & 3.05 & 20.04 & 2.75 \\
F & 60 & 6.86 & - & 6.86 & 6.86 \\
X & 60 & 9.39 & 1.78 & 13 & 6.31 \\
\hline
\end{tabular}

Table V. Distribution of palatal rugae according to the 5 quadrants that was divided the palate.

\begin{tabular}{|c|c|c|c|c|c|}
\hline Palatine rugae position & $\mathbf{n}$ & Mean & SD & Maximum & Minimum \\
\hline \multicolumn{6}{|l|}{ Females } \\
\hline Zona A & 60 & 0.016 & 0.12 & 1 & 0 \\
\hline Zona B & 60 & 0.41 & 0.54 & 3 & 0 \\
\hline Zona C & 60 & 0.016 & 1.74 & 3 & 0 \\
\hline Zona D & 60 & 0.86 & 1.25 & 6 & 0 \\
\hline Zona E & 60 & $1.31^{*}$ & 2.16 & 9 & 0 \\
\hline \multicolumn{6}{|l|}{ Males } \\
\hline Zona A & 60 & 0.016 & 0.12 & 1 & 0 \\
\hline Zona B & 60 & 0.5 & 0.68 & 2 & 0 \\
\hline Zona C & 60 & 0.51 & 0.72 & 2 & 0 \\
\hline Zona D & 60 & 1.01 & 1.39 & 4 & 0 \\
\hline Zona E & 60 & $1.53 *$ & 2.1 & 6 & 0 \\
\hline \multicolumn{6}{|l|}{ Total } \\
\hline Zona A & 120 & 0.016 & 0.12 & 1 & 0 \\
\hline Zona B & 120 & 0.46 & 0.68 & 3 & 0 \\
\hline Zona C & 120 & 0.49 & 0.72 & 3 & 0 \\
\hline Zona $\mathrm{D}$ & 120 & 0.95 & 1.39 & 6 & 0 \\
\hline Zona E & 120 & $1.53^{*}$ & 2.1 & 9 & 0 \\
\hline
\end{tabular}


suspects to crime scenes because such tests are not expected to find in such circumstances. It is also possible to consider the possibility of falsification of the pattern of rugae in cases toothless. Gitte et al. (1999) describe a method that palatal rugae are added to the palate maxillary complete dentures to improve the patterns of verbal expression and phonetics in some patients. This process can lead to the false identity of exclusion due to ante-mortem data misleading.

It is important to note the existence of abnormal patterns and shapes on palatal rugae, these anomalies are considered as a reflection of alterations in the normal growth of the palate. It has been suggested that these abnormal patterns can be used as an additional feature or sign in the diagnosis of cleft palate in humans (Ikemi et al., 2001) and have been used as benchmarks when testing in pre-and postsurgical cleft palate surgery (Park et al., 1994).

In conclusion, the palatal rugae are very important in dental and forensic practice. Can be used to evaluate the dental movements, as they remain stable over a person's life. In addition, show a significant association between shapes and ethnicity. Finally, the palatal rugae can be used as a reliable guide to the forensic identification.

HERMOSIlla, V. V.; SAN PEDRO, V. J.; CANTÍN, L. M. \& SUAZO, G. I. C. Rugas palatinas: sistematización del análisis de su forma y dimensiones para su uso en identificación humana. Int. J. Morphol., 27(3):819-825, 2009.

RESUMEN: Establecer la identidad de una persona puede ser un proceso muy complejo, siendo uno de los principales objetivos de las ciencias forenses. El análisis de las piezas dentarias, huellas digitales y comparación del ADN, son probablemente las técnicas más usadas, siendo rápidas y seguras para el proceso de identificación. Sin embargo, estas técnicas no siempre pueden ser aplicadas, siendo en ocasiones necesario aplicar técnicas diferentes y menos conocidas. En este trabajo, se realizó un análisis sistemático de la forma y las dimensiones de las rugas palatinas. Fueron analizados 120 sujetos de ambos sexos, entre 15 a 20 años, completamente dentados, mediante calculorrugoscopia se determinaron la forma, tamaño, número y posición de las rugas palatinas. La forma de rugas palatinas más prevalente fue la ondulada (43\%) seguido de la forma curva $(27 \%)$, la forma recta (15\%), el tipo punto (11\%), las variedades polimorfas (4\%). El número promedio fue de 12,27 , siendo mayor en hombres que en mujeres. Las rugas palatinas que resultaron de mayor tamaño fueron las rugas onduladas (media 9,58 mm). El 40\% de las rugas se encontraron en el cuadrante E, seguido de D (30\%), el resto se distribuyó en las otras regiones. El análisis las rugas palatinas y sus características pueden ser utilizadas como una guía fiable en la identificación forense.

PALABRAS CLAVE: Rugas palatinas; Paladar; Rugoscopía; Forense; Identificación humana.

\section{REFERENCES}

Amasaki, H.; Ogawa, M.; Nagasao, J.; Mutoh, K.; Ichihara, N.; Asari, M. \& Shiota, K. Distributional changes of BrdU, PCNA, E2F1 and PAL31 molecules in developing murine palatal rugae. Ann. Anat., 185(6):517-23, 2003.

Almeida, M. A.; Phillips, C.; Kula, K. \& Tulloch, C. Stability of the palatal rugae as landmarks for analysis of dental casts. Angle Orthodont., 65(1):43-8, 1995.

Buchtová, M.; Tichy, F.; Putnová, I. \& Mísek, I. The development of palatal rugae in the European pine vole, Microtus subterraneus (Arvicolidae, Rodentia). Folia Zoo., 52 (2):127-36, 2003.

Caldas, I. M.; Magalhães, T. \& Afonso, A. Establishing identity using cheiloscopy and palatoscopy. Forensic Sci. Int., 165(1):1-9, 2007.
English, W. R.; Robison, S. F.; Summitt, J. B.; Oesterle, L. J.; Brannon, R. B. \& Morlang, W. M. Individuality of human palatal rugae. J. Forensic Sci., 33(3):718-26, 1988.

Gegenbaur, C. Die Gaumenfalten des Menschen. Morph. Jb., 4:573-83, 1878.

Gitto, C. A.; Exposito, S. J. \& Draper J. M. A simple method of adding palatal rugae to a complete denture. J. Prosthet. Dent., 81:237-9, 1999.

Ikemi, N.; Otani, Y.; Ikegami, T. \& Yasuda, M. Palatal ruga anomaly induced by all-trans-retinoic acid in the Crj:SD rat: possible warning sign of teratogenicity. Reprod. Toxicol., 15(1):87-93, 2001. 
Jordanov, J. A. Growth of the hard palate in man. Anthropological characteristics. Z. Morphol. Anthropol., 63(2):230-7, 1971.

Kapali, S.; Townsend, G.; Richards, L.; Parish, T. Palatal rugae patterns in Australian Aborigines and Caucasians. Aust. Dent. J., 42(2):129-33, 1997.

Lang, J. \& Baumeister, R. Postnatal development of the width and height of the palate and the palate foramina. Anat. Anz., 155(1-5):151-67, 1984.

Limson, K. S. \& Julian, R. Computerized recording of the palatal rugae pattern and an evaluation of its application in forensic identification. J. Forensic Odontostomatol., 22(1):1-4, 2004.

Muthusubramanian, M.; Limson, K. S. \& Julian, R. Analysis of rugae in burn victims and cadavers to simulate rugae identification in cases of incineration and decomposition. J. Forensic Odontostomatol., 23(1):26-9, 2005.

Ohtani, M.; Nishida, N.; Chiba, T.; Fukuda, M.; Miyamoto, Y. \& Yoshioka, N. Indication and limitations of using palatal rugae for personal identification in edentulous cases. Forensic Sci. Int., 176(2-3):178-82, 2008.

Park, S.; Eguti, T.; Kato, K.; Nitta, N. \& Kitano, I. The pattern of palatal rugae in submucous cleft palates and isolated cleft palates. Br. J. Plast. Surg., 47(6):395-9, 1994.

Patil, M. S.; Patil, S. B. \& Acharya, A. B. Palatine rugae and their significance in clinical dentistry: a review of the literature. J. Am. Dent. Assoc., 139(11):1471-8, 2008.

Peavy, D. C. Jr. \& Kendrick, G. S. The effects of tooth movement on the palatine rugae. J. Prosthet Dent., 18(6):536-42, 1967.

Preethi, N.; Ashith, B.; Padmini, A. T. \& Kaveri, H. Differences in the palatal rugae shape in two populations of India. Arch. Oral Biol., 52:977-82, 2007.

Pueyo, V. M.; Garrido, B. R. \& Sánchez, J. A. S. Odontología Legal y Forense. Barcelona, Masson, 1994. pp.277-92.

Reuer, E. Gaumentleistein und Gaumerferm bei drei lokalen populationen in Osterreich. Mitteilungen der Anthropologischen Gesellschaft in Wien, 103:1-3, 1973.

Thomas, C. J. \& van Wyk, C. W. The palatal rugae in an identification. J. Forensic Odontostomatol., 6(1):21-7, 1988.
Thomas, C. J.; Kotze, T. J. \& Van der Merwe, C. A. An improved statistical method for the racial classification of man by means of palatal rugae. Arch. Oral Biol., 32(4):315-7, 1987.

Utsuno, H.; Kanoh, T.; Tadokoro, O. \& Inoue, K. Preliminary study of postmortem identification using lip prints. Forensic Sci. Int., 149(2-3):129-32, 2005.

Waterman, R. E. \& Meller, S. M. Alteration in the epithelial surfaces of human palatal shelves prior to and during fusion: a scanning electron microscope study. Anat. Rec., 180:111-36, 1974

Yamazaki, Y. Cross-sectional study of plicae palatinae transversae in the Japanese. Anthropol. Rep. Niigata, 34:59-76, 1962.

Correspondence to:

Prof. Dr. Iván Suazo Galdames

Departamento de Morfología

Universidad de Talca

CHILE

Email: isuazo@utalca.cl

Received: 28-05-2009

Accepted: 26-07-2009 
